\title{
Lower Jurassic Ostracod Biozonation of the Mochras Borehole
}

\author{
IAN D. BOOMER \\ School of Environmental Sciences, University of East Anglia, Norwich, NR4 7TJ.
}

\begin{abstract}
The extensive Lower Jurassic sequence at Mochras has yielded a diverse ostracod fauna which includes many new taxa. Poor preservation precludes a complete taxonomic review of this material although four new species (Cytherella praetoarcensis, Ogmoconcha convexa, Lophodentina striata and Oligocythereis? mochrasensis) are erected herein. Changes in the faunal composition and the rates of faunal turnover are briefly described. An ostracod biozonation is proposed for the section, comparison with established Lower Jurassic zonal schemes reveals that the present section is distinct from most other European sequences.
\end{abstract}

\section{INTRODUCTION}

The Llanbedr or Mochras Farm borehole was sited approximately three kilometres west of Llanbedr village, North Wales (National Grid Reference SH 5533 2594). The sequence at Mochras comprises an uppermost $80 \mathrm{~m}$ of till which overlies $500 \mathrm{~m}$ of Tertiary lacustrine clays. Below this are $1300 \mathrm{~m}$ of sediments covering most of the Lower Jurassic period which are underlain by $30 \mathrm{~m}$ of Triassic brecciated carbonates. The borehole was cored throughout (Wood \& Woodland, 1968).

\section{LITHOLOGY}

The Lower Lias (Hettangian to Lower Pliensbachian) is principally developed as an alternating series of hard, medium grey, argillaceous siltstones and softer, dark grey, calcareous, silty and commonly micaceous mudstones with numerous thin bands and nodules of limestone distributed irregularly throughout. The upper part of the Lower Lias is more massive than the lower, with an increase in lamination and fewer developments of bituminous sediments. The Middle Lias (effectively Upper Pliensbachian) is a continuation of the massively bedded underlying unit; this stratigraphical interval is a great contrast to other parts of Britain in that it lacks any ferruginous deposits and has negligible arenaceous sediment. The Upper Lias (Toarcian) consists of alternating, dark grey, silty mudstones and argillaceous siltstones. As in the Middle Lias, boundaries are generally gradational. A more detailed description is given in the original I.G.S. Report (Woodland (ed) 1971).

From a total of 147 samples examined, about 360 ostracod 'taxa' were identified; these include'lumped' groups such as Polycope spp. and many unidentified forms. In total 30,877 valves were recovered of which $17,750(57 \%)$ were recorded as carapaces. Variation in the sediment type and degree of lithification often resulted in poor preservation, particularly in the Sinemurian and Pliensbachian with the best preservation in the Toarcian.

\section{BIOSTRATIGRAPHY}

Many new, small species (i.e. adults $<0.4 \mathrm{~mm}$ long) were recovered, however, the poor preservation and low abundance of many of these forms precludes their description in the present work. The larger ostracods recovered from Mochras notably exclude many, otherwise ubiquitous, Lower Jurassic species. Whether this is as a result of primary (i.e. environmental) or secondary (i.e. diagenetic and/or processing loss) factors is unknown.

The Hettangian sediments from Mochras have faunas typical of most contemporary NW European assemblages with Ogmoconchella aspinata Drexler dominating and Ogmoconcha hagenowi Drexler appearing towards the top of the stage. The taxa described by Klingler \& Neuweiler (1959) from the Sinemurian of north-west Germany are not common in the Mochras section. Ainsworth (1987) recorded well-preserved specimens from the Upper Sinemurian of the Fastnet Basin which he attributed to the genus Klinglerella Anderson. The present author considers such material to belong to the genus Ektyphocythere Bate and believes that the Sinemurian species from Mochras, although poorly preserved, are closely related to Ainworth's material. Ainsworth (in prep.) confirms that new species of Sinemurian Ektyphocythere are present both in Mochras and in the Fastnet Basin.

Many Lower Pliensbachian sediments from North-West Europe are characterised by the presence of Gammacythere ubiquita Malz \& Lord. In Mochras only two valves of the species are recorded from this interval. Closely related species 
from the same level such as Gammacythere klingleri (Boomer, in press = Ostracod 19 Klingler, 1962) and Gammacythere foveolata (Michelsen) are also rare in the Mochras section. These species are, however, generally abundant in the Dorset Coast sediments. Upper Pliensbachian sediments from Europe typically contain Grammanella apostolescui (Gramann) a species which is only rarely ( 2 specimens) recorded from Mochras. The faunal record for the Toarcian interval at Mochras is much more closely related to coeval assemblages from other parts of Europe.

With respect to the above observations it should be noted that in many Sinemurian and Pliensbachian samples there are few large $(>0.4 \mathrm{~mm})$ ostracods present; their presence is often recorded only by fragments. Where they do occur, carapaces are more readily preserved than single valves. This is not simply a result of sorting since assemblages of carapaces are often accompanied by many valve fragments which may have been produced by the techniques employed in processing the samples. This is true for Cytheracea, Cypridacea and Metacopina alike; the latter group being notably rare in certain intervals and poorly known in others (see fig. 2).

When comparing the zonation of the Danish Embayment (Michelsen, 1975) to the present section it appears that of the seven taxa characterising the former scheme three of them have not been positively identified in Mochras $(N$. simplex, $K .(K)$. foveolata (=Gammacytherefoveolata) and $P$.reticulata) while two of the remaining species are relatively rare (G.apostolescui and. danica). Thus it would appear that a direct faunal comparison between Mochras and other parts of NW Europe is not possible at all levels. The faunas from certain stratigraphical levels show little or no similarity to contemporary assemblages elsewhere while other assemblages, particularly in the Hettangian and Toarcian, bear stronger affinities. The Mochras section does, however, add new information on the spatial and temporal distribution of some well-known species. Reference is made below to Toarcian material from Ilminster, Somerset currently in-press (Boomer et al.).

\section{SYSTEMATICS}

Specimens deposited at the British Geological Survey, Keyworth, Nottingham; $F=$ Female, $M=$ Male. Order Podocopida Muller, 1894

Suborder Platycopina Sars, 1866 Family Cytherellidae Sars, 1866
Genus Cytherella Jones, 1849

Type species: Cytherina ovata Roemer, 1840

Cytherella praetoarcensis sp. nov.

(Pl.2, figs 4, 5, 9).

Derivation of name: With reference to the stratigraphical occurrence of the species, with respect to Cytherella toarcensis, at the type locality (Mochras Borehole).

Diagnosis: A species of Cytherella with the greatest length above mid-height due to the presence of a distinctive, steeply sloping postero-ventral margin in lateral view.

\section{Holotype: M LV MPK 6465}

Type locality and Horizon: Mochras Borehole, Wales, Grid Ref. SH 5533 2594. Sample MOC-080 (depth 717.73-719.15 metres), lower variabilis zone, Middle Toarcian, Lower Jurassic. Description: In lateral outline, RV broadly rounded, anterior margin becoming straight to slightly convex ventrally and straightens onto the postero-ventral margin. A sharp angle is formed on the posterior margin at about two-thirds of the height, where it turns sharply onto the slightly convex posterodorsal margin. Greatest height just posterior of mid-length. LV differs from RV in that the ventral margin of the former is straight to slightly concave, a feature most marked in the more elongate (?)male dimorphs. Dorsal apex more strongly marked in LV.

RV overlaps LV entirely except in the dorsal half of the anterior margin where the two coincide. Overlap is strongest just anterior of the greatest height. The overlap is never as strongly developed ventrally as seen in $C$. toarcensis. Outline lanceolate in dorsal view with a well-rounded posterior margin. Maximum width at approximately one third of the length from the posterior. Well preserved specimens display fine anteromarginal reticulation. Muscle scar patterns not clearly observed although in some specimens an indistinct raised area was recorded internally. No external muscle sulcus present, however, the species shows weak dorso-median compression. Dimensions: Size ranges are given below for $\mathrm{LV}$ and $\mathrm{RV}$ of both $o$ and $o$ valves.

$$
\begin{array}{lll}
\text { RV } & \text { M } & l=0.75-0.77 \mathrm{~mm} \mathrm{~h}=0.49-0.52 \mathrm{~mm} ; \\
& F & l=0.76-0.80 \mathrm{~mm} \mathrm{~h}=0.51-0.53 \mathrm{~mm} ; \\
\text { LV } & \text { M } & \mathrm{l}=0.76-0.80 \mathrm{~mm} \mathrm{~h}=0.50-0.52 \mathrm{~mm} ; \\
& \text { F } & l=0.73-0.74 \mathrm{~mm} \mathrm{~h}=0.46-0.48 \mathrm{~mm} ;
\end{array}
$$

Remarks: Very similar to $C$. toarcensis Bizon but can be differentiated by the posterior to ventral outline in lateral view. $C$. toarcensis possesses a very rounded posterior margin, whereas

Figs 1, 5, 7, 8. Ogmoconcha convexa sp. nov.

\section{Explanation of Plate 1.}

la-b. (SP) Holotype MPK 6451 Car, right lateral, (Ur tenuicostatum, 835.08-836-57m) x73. 5a-b. (SP) Paratype MPK 6452 Car, dorsal, (Ur tenuicostatum, 835.08-836.57m) x73. 7. Paratype MPK 6453 Car, right lateral, (Ur tenuicostatum, 835.08-836.57m) x70. 8. Paratype MPK 6454 o LV, internal, (Ur tenuicostatum, 835-08-836.57m) x64. Figs 2-4. Oligocythereis? mochrasensis sp. nov. 2.Car, Paratype MPK 6455 dorsal, (Lr tenuicostatum, 861.52-862.84m) x95. 3a-b. (SP) Holotype MPK 6456 RV, external, (Ur spinatum, 867.08-868.48m) x95. 4.(SP) Paratype MPK 6457 RV, internal, (Ur spinatum, 867.08-868.48m) x95. Fig. 6. Oligocythereis? sp. 6b. (SP) MPK 6458 LV Adult, external, (Lr levesquei, 646.48-647.78m) x94. Fig. 9. Paracytheridea? sp. 9a-b. (SP) MPK 6459 LV Adult, external, (Lr jamesoni, 1220.77-1219.30m) x94. 


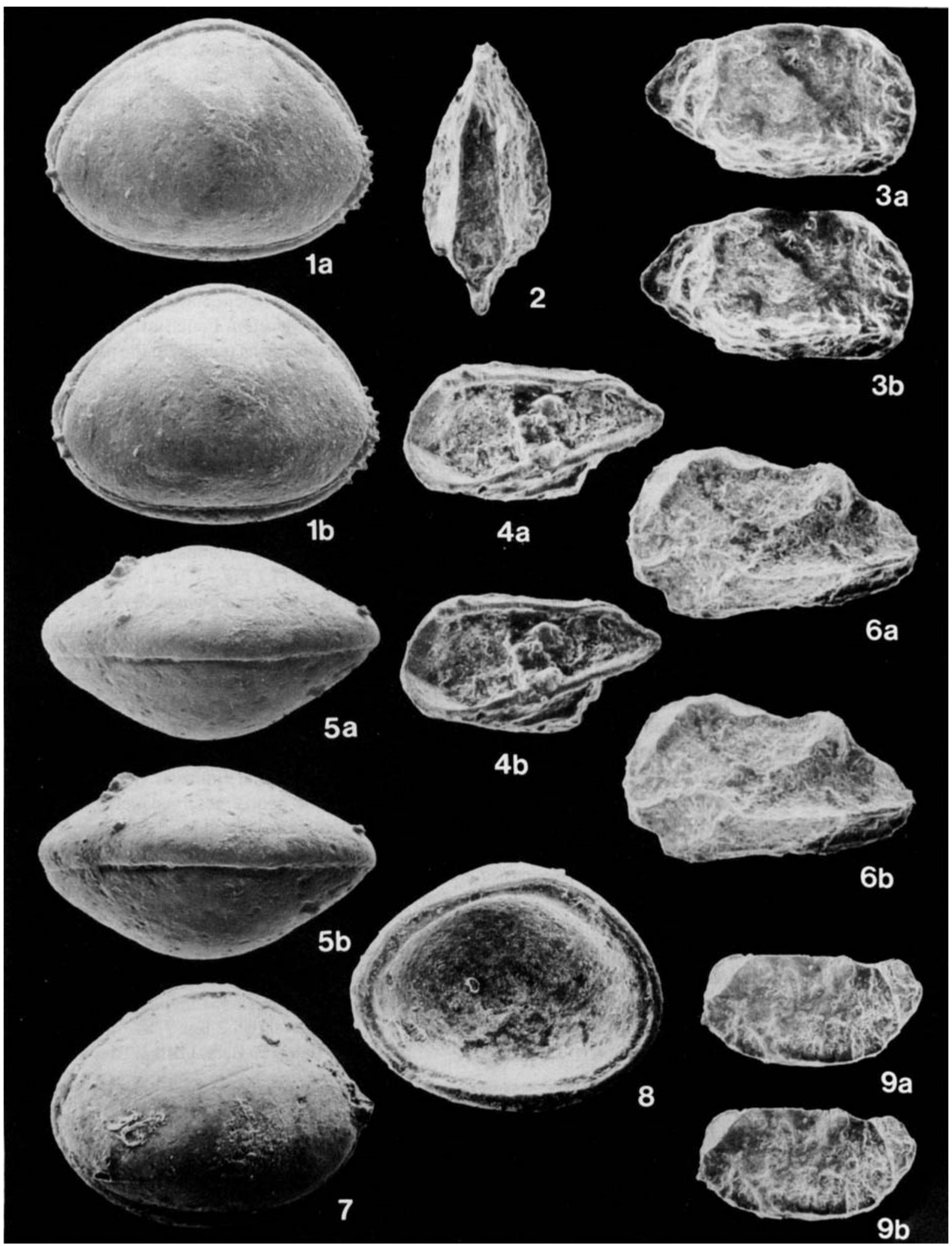


the present species has a distinctly sloping postero-ventral margin, producing a more angular shape at the posterior margin. The present species is further distinguished by the inclined antero-dorsal margin (rounded in C.toarcensis) and the weaker overlap. The carapace outline and relative stratigraphical position indicates that the present species is directly ancestral to C. toarcensis. The transition between these two species can be observed in the upper variabilis zone of the Mochras Borehole. Distribution: Bifrons zone of Ilminster and upper falciferum to upper variabilis zones of Mochras. Based on these stratigraphical ranges it is likely that specimens of $C$. toarcensis described from Middle and Upper Toarcian sediments elsewhere may belong to, or include representatives of, the new species. It should be noted however that the type description of the former species (Bizon, 1960 p.203) gives the range as bifrons and jurense (variabilis) zones and therefore the transition between the two species may not have been synchronous throughout Europe.

Family Healdiidae Harlton, 1933

Genus Ogmoconcha Triebel, 1941

Type Species: Ogmoconcha contractula Triebel, 1941

Ogmoconcha convexa sp. nov.

(Pl.1. figs 1, 5, 7, 8).

1987 Ogmoconcha aff. rotunda Dreyer; Ainsworth: 57, Pl.3, figs $3,5,6$.

Derivation of name: With reference to the carapace outline in dorsal view which distinguishes the species.

Diagnosis: A species of Ogmoconcha with distinctly convex lateral surfaces in dorsal view.

Holotype: Adult (?Male) Car, MPK 6451

Material: Mochras, $>100 \mathrm{Car},>100 \mathrm{~V}$; Ilminster, $8 \mathrm{Car}, 15 \mathrm{~V}$. Type locality and Horizon: Mochras Borehole, Wales, Grid REf. SH 5533 2594. Sample MOC-161 (depth 835.08-836.57 metres), upper tenuicostatum zone, Lower Toarcian, Lower Jurassic.

Description: Lateral carapace outline is oval triangular. Ventral margin convex, particularly so in the more rounded female(?) morphotypes. Broadly rounded anterior margin bearing four to seven small marginal denticles. Greatest height anterior of midpoint. Postero-dorsal margin slopes steeply to a narrowly rounded posterior margin which may bear up to three small denticles. Lateral surfaces smooth and convex with the greatest width just posterior of the mid-length, the line of greatest length being just below the mid-height. Overlap ( $L V>R V)$ strong but narrowing slightly along the postero-dorsal margin and at the anterior extremity.

Dimensions:

Adult RV l $=0.69-0.73 \mathrm{~mm} \mathrm{~h}=0.47-0.54 \mathrm{~mm}$

Adult LV l=0.74-0.79mm $\mathrm{h}=0.52-0.58 \mathrm{~mm}$

Remarks: The species is easily distinguished from amalthei and contractula both of which have flattened lateral surfaces. The lateral carapace outline is similar to that of Ogmoconcha hagenowi Drexler, however, the present material lacks the lateral surface pitting of the former, smaller, species. The point of greatest height lies just in front of mid-length in the present species, whereas in hagenowi the same point lies more distinctly anteriorly.

Drs H. Malz and A.R. Lord have compared the present species with type and other comparative material deposited in the Senckenberg Museum, Frankfurt. Their study concluded that the largest specimens (adults) of the present material were of a size comparable to the A-1 instars of Ogmoconcha amalthei (Quenstedt, 1858). The adults and late instars of that species are distinguished by flattened lateral surfaces and dorso-lateral compression. The fact that these features are not seen on any of the present specimens, together with the stratigraphical separation, supports the author's view that a new species exists. The possible presence of sexual dimorphism in the largest specimens suggests that mature animals are represented (compare Pl.1 Fig.1 M? with Pl.1 Fig.7 F?).

Ainsworth (1987) recorded Ogmoconcha aff. rotunda Dreyer from the Upper Pliensbachian of the Fastnet Basin. The present author considers that material to be synonymous with the present species as evidenced by the geographical proximity, stratigraphical occurrence and a comparison of the figured material. Furthermore the size range of Ainsworth's material fits within that of. convexa.

Distribution: Present at Ilminster (tenuicostatum zone) although only as a few poorly preserved specimens; mid-spinatum to upper tenuicostatum zone at Mochras where it dominates the assemblages towards the top of its range; Upper Pliensbachian and probably Lower Toarcian of the Fastnet Basin (Ainsworth, 1987).

Family Cytheridae Baird, 1850

Genus Lophodentina Apostolescu, 1959

Type species: Lophodentina lacunosa Apostolescu, 1959

Lophodentina striata sp. nov.

(Pl.2 figs 7, 8)

?1984 Gen. Indet. C. Bate, Lord \& Riegraf: P1.5, fig.6.

Figs. 1-2. Ektyphocythere bizoni Ainsworth, 1986.

\section{Explanation of Plate 2}

1a-b. (SP) Specimen lost. o RV, internal (Ur levesquei, 605.43-606.88m) x100. 2a-b. (SP) MPK 6461 o LV, external, (Ur levesquei, 608.30608.90m) x100. Fig. 3. Lophodentina sp. A. 3. MPK 6462 o CP, external, (Lr semicostatum, 1644.09-1645.51m) x94. 4. Paratype MPK 6436 o Car, left lateral, (Mid-variabilis, 704.01-705.26m) x66. 5. Paratype MPK 6464 o RV, external, (Mid-variabilis, 717.73-719.15m) x73. 9a-b. Paratype MPK 6464 o RV, external, (Mid-variabilis, 717.73-719.15m) x71. Fig. 6. Acrocythere? michelseni Finger, 1983. 6. Specimen lost LV Adult, external, (Ur levesquei, 603.91-605.43m) x161. Figs 7, 8. Lophodentina striata sp. nov. 7. Paratype MPK 6466 LV Adult, internal, (Lr margaritatus, 986.48-987.93m) x97. 8a-b. (SP) Holotype MPK 6467 Car, Adult, left lateral, (Ur spinatum, 865.66-867.08m) x95. 


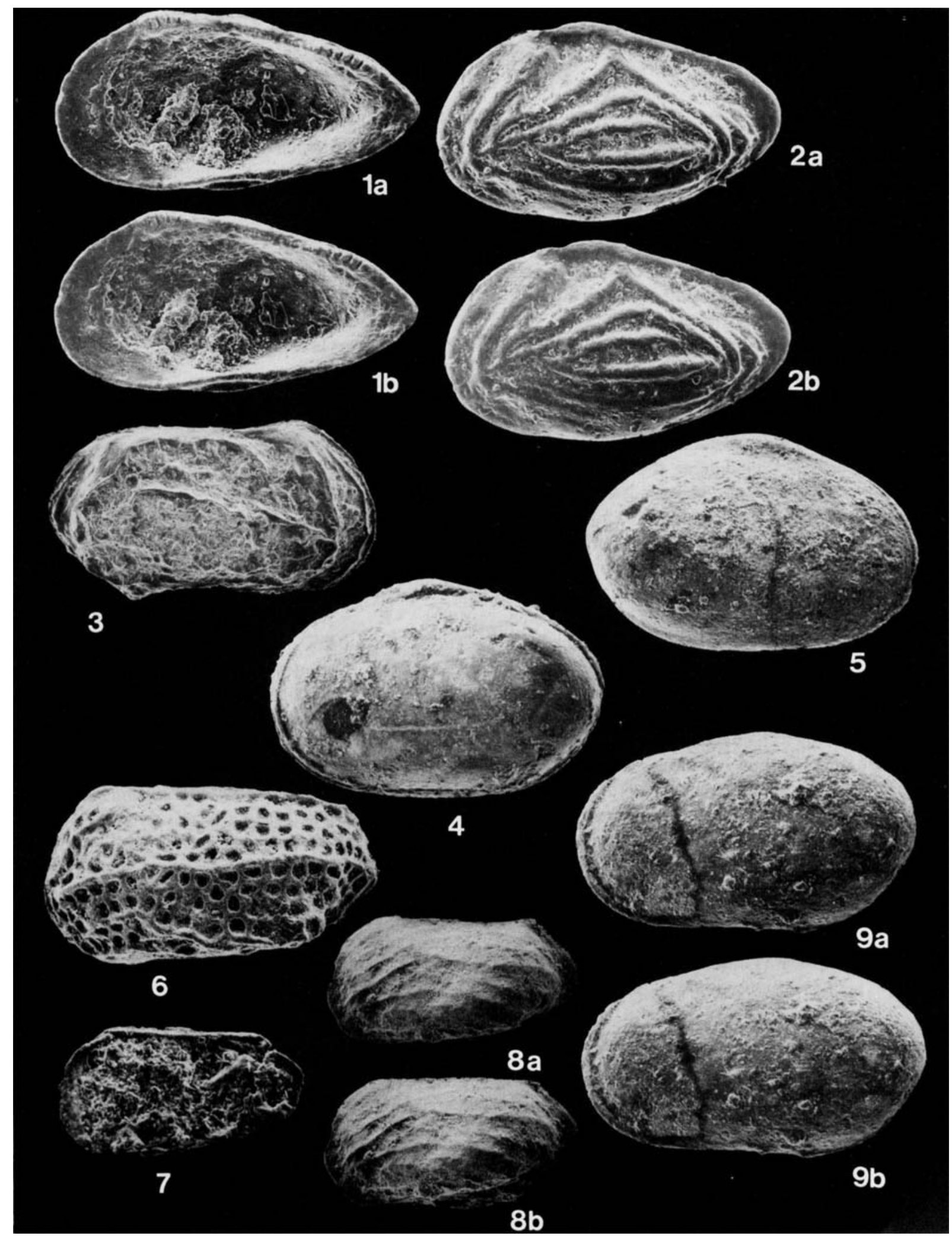


Derivation of name: With reference to the lateral surface ornament of fine discontinuous striae.

Diagnosis: A small species with a bilobate carapace, a straight dorsal margin and discontinuous, sinuous striae on the lateral surfaces.

Holotype: Car, Adult MPK 6467

Material: Mochras, $45 \mathrm{Car}, 19 \mathrm{~V}$

Type locality and horizon: Mochras Borehole, Grid Ref. SH 5533 2594. Sample MOC-265 (depth 986.48-987.93 metres) lowest stokesi subzone, margaritatus zone, Upper Pliensbachian. Description: Carapace elongate oval in lateral view with slight mid-ventral and mid-dorsal concavities. Anterior and posterior margins broadly rounded. In dorsal view the carapace appears as two distinct swellings or lobes separated by a broad, weak median depression. A marginal rim is present along both anterior and posterior margins. The posterior lobe is the broader of the two but this feature is not thought to be dimorphic. In posterior view the greatest width is just below the mid-height. The greatest height is anterior of the mid-point and the greatest length is at the mid-height. Valve surfaces are omamented with three or four short sinuous striae running at a slightly oblique angle from postero-dorsal to antero-ventral. The internal details are poorly known. The hinge appears to be lophodont.

Dimensons: Adults l $=0.41-0.45 \mathrm{~mm}, \mathrm{~h}=0.20-0.24 \mathrm{~mm}$

Remarks: Although apparently much smaller than previously described members of this genus the present material has been assigned to this taxon due to the similarity in carapace shape, outline and the presence of what appears to be a lophodont hinge. Material described by Bate, Lord \& Reigraf (1984) from D.S.D.P. Leg 79, site 547 includes a species similar to the present material from sediments which those authors consider to be of Pleinsbachian age. Their figured specimen $(0.32 \mathrm{~mm}$ long) has a similar lateral outline and surface ornament to the present material. The material figured by Bate $e t$ al. (deposited at Tubingen) has not been studied and although other residue from those samples was made available, further specimens were not recovered from site 547 . A direct comparison between the two was therefore not possible.

Distribution: A distinctive species representing a small but consistent part of Upper Sinemurian and Lower Pliensbachian assemblages from the Mochras Borehole.

Lophodentina sp. A.
(Pl.2 fig.3)

Material: Mochras, $8 \mathrm{Car}, 20 \mathrm{~V}$.

Description: Carapace elongate, quadrate with a broadly rounded anterior margin, a straight ventral and a sub-parallel, sinuous dorsal margin, the latter having a concavity just behind the anterior cardinal angle. Posterior margin narrowly rounded, greatest length at the mid-height. Greatest height at the anterior cardinal angle which bears an indistinct eye-spot from which two ribs run parallel to the anterior margin, one on the compressed marginal area and the other on the inflated part of the valve. A flattened marginal rim is present anteriorly, dorsally and posteriorly. The mid-valve region is inflated, most notably so towards the ventral margin.

The lateral surface is ornamented by dominant longitudinal ribbing which breaks up ventrally to form a coarse reticulation. On the postero-lateral surface two parallel oblique ribs run from the posterior margin to the mid-valve region, from where another rib runs to the antero-ventral margin. The dorso-lateral region bears a rib which, anteriorly, turns onto the lateral surface for a short distance. From the poorly preserved nature of the present material it is not possible to determine the nature of the intercostal surface. Internal details not observed. Sexual dimorphism present.

\section{Dimensions:}

$$
\begin{array}{lll}
\text { M } & \text { LV } & \mathrm{l}=0.62-0.64 \mathrm{~mm}, \mathrm{~h}=0.32-0.34 \mathrm{~mm} ; \\
\text { M } & \text { RV } & \mathrm{l}=0.57 \mathrm{~mm}, \mathrm{~h}=0.30 \mathrm{~mm} ; \\
\text { F } & \text { LV } & \mathrm{l}=0.60 \mathrm{~mm}, \mathrm{~h}=0.30 \mathrm{~mm} \\
\text { F } & \text { RV } & \mathrm{l}=0.52 \mathrm{~mm}, \mathrm{~h}=0.32 \mathrm{~mm}
\end{array}
$$

Remarks: Lophodentina species described from the Lower Jurassic are generally similar to the material presently under discussion. The exact taxonomic position of $L$. crepidula (Tate \& Blake, 1876) remains uncertain, as with most of the material described in that early work. The species described by Apostolescu, 1959 (L. lacunosa, L. pumicosa), Drexler, 1958 (L. bicostata), and Donze, 1966 (L. convergens) all apparently differ from the present material in the form of the ornament, but one (or more?) of these taxa may later prove to be conspecific and for that reason open nomenclature is employed. The genus is clearly an important constituent of Hettangian and Lower Sinemurian assemblages throughout Europe, but there do not appear to be any geographically widespread species.

\section{Explanation of Plate 3.}

Fig. 1. Cytheropteron? aff. C. Cavatum Michelsen. la-b. (SP) MPK 6468 Car. Adult (?) left lateral, (Lr margaritatus, 1000.43-1001.90m) x 154. Fig. 2. Cytheropteron? Sp. A. 2. MPK 6469 RV Adult (?), external (Lr margaritatus, 979.52-980.90m) x 170. Fig. 3. Cristacythere crassireticulata Michelsen. 3. Specimen lost - o Car, right lateral, (Mud-turneri, 1503.38-1501.85m) x 100. Fig. 4. Cristacythere osmanvillae (Donze). 4. MPK 6470 o LV, external, (Lr buckalandi, 1715.06-1716.53m) x102. Fig. 5. Cardobaridia cf. C. fastnetensis Ainsworth. 5. MPK 6471 Car Adult, right lateral, (Ur levesquei, 606.88-608.30m) x94. Figs 6, 8-10. Pleurocythere sp. A. 6. MPK 6472 o LV, external, (Ur levesquei, 609.80-611.30m) x85. 8. MPK 6473 o LV, internal, (Ur levesquei, 605.43-606.88m) x93. 9. MPK 6474 o LV, external, (Ur levesquei, 609.80-61 1.30m) x85. 10. MPK 6475 o RV, external, (Ur levesquei, 605.43-606.88m) x92. Fig. 7. Pleurocythere sp. B. 7a-b. (SP6476 MPK LV Adult (?), external, (Ur ibex, 1043.65-I044.99m) x92. 


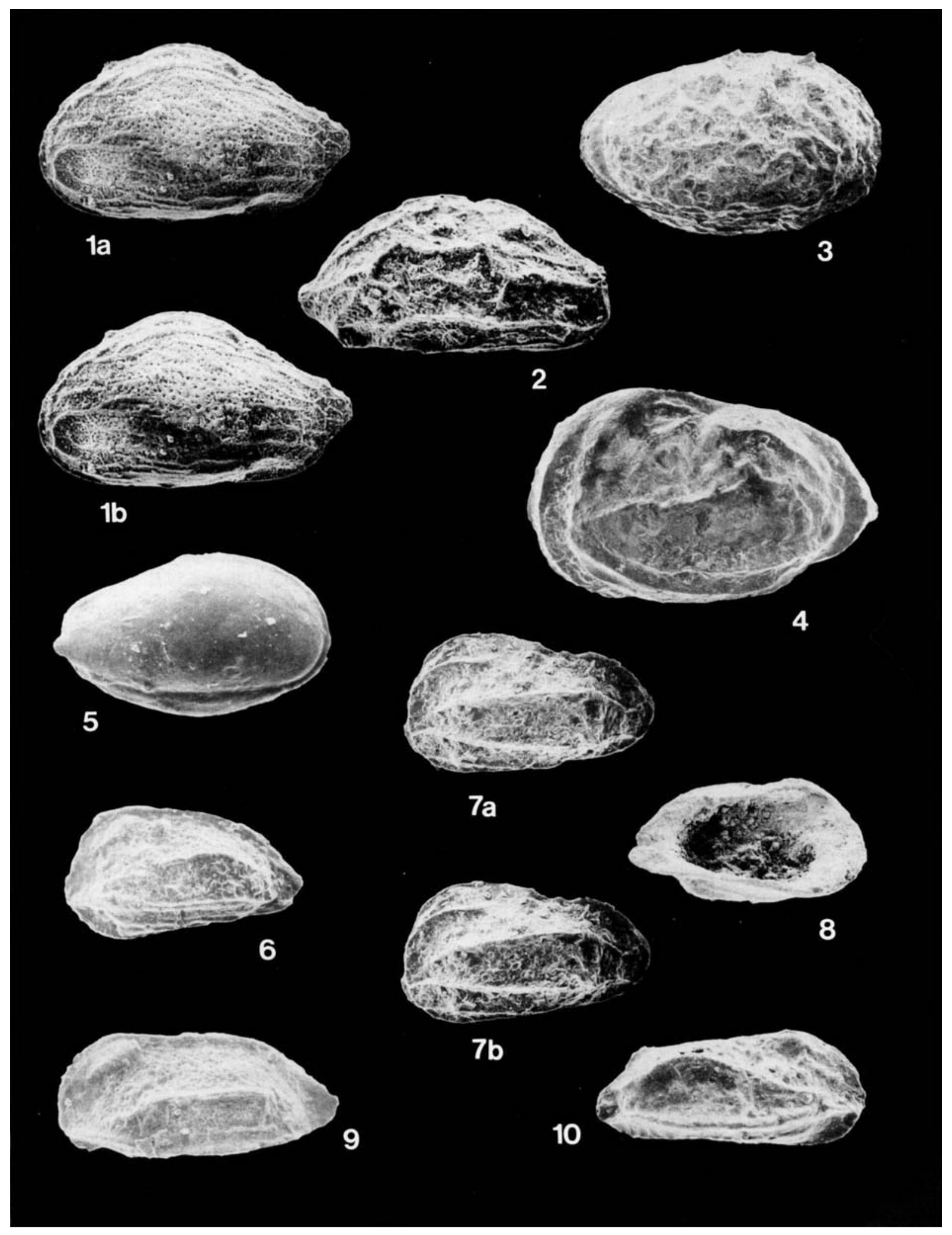


Distribution: Semicostatum, turneri and obtusum zones, Sinemurian of Mochras.

Genus Oligocythereis Sylvester-Bradley, 1948

Type species: Cythereis fullonica Jones \& Sherborn, 1888

Remarks: Two similarly ornamented species with concurrent stratigraphical ranges in the Mochras section were tentatively assigned to this genus. Of these only the more common is described as a new species. The carapaces of these species have a broadly rounded anterior margin with the greatest height at the anterior cardinal angle. Ventral margin is straight to sinuous while the dorsal margin is broadly convex in the RV, less so in the smaller LV. Both species are so poorly preserved that internal details are virtually unknown and even exterior ornamental features are often completely obscured. The majority of specimens recovered were juvenile forms. The two species are doubtfully assigned to the same genus although neither can be ascribed with certainty to any known taxon.

Distribution: One of the factors supporting a close relationship between the two is their stratigraphical distribution. Both species range from the upperr. ost spinatum zone, Upper Pliensbachian, through to the top of the tenuicostatum zone, Lower Toarcian. The lesser known species, Oligocythereis? sp. (Pl.1 fig.6), also has a few well-preserved records in the Upper Toarcian.

\section{Oligocythereis? mochrasensis sp. nov.}

(P1.1 figs 2-4)

?1984 Gen. indet. D. Bate, Lord \& Riegraf: Pl.5, figs 9, 11. Derivation of name: Named after the type locality of Mochras. Diagnosis: Characterised by the presence of two weak vertical ribs on the lateral surfaces, which are connected both dorsally and ventrally by longitudinal ribs.

Holotype: Female RV MPK 6456

Material: Mochras, $2 \mathrm{Car}, 178 \mathrm{~V}$.

Type locality and horizon: Mochras Borehole, Wales. Grid Ref. SH 5533 2594, MOC-180 (depth 867.08-868.48 metres), Upper spinatum zone, Lower Toarcian.

Description: Carapace lanceolate in dorsal view (see Pl.1 fig.2). Short, acuminate posterior margin and anterior margin both compressed. Greatest breadth at postero-ventral angle, which marks the lateral extent of the longitudinal rib which begins at the anterior margin and terminates just in front of the posterior margin. Just above the anterior end of this rib is a faint trace of a parallel rib which disappears rapidly towards the midvalve area.

A short dorsal flange is present which obscures the hinge line in lateral view. Anterior end of flange is swollen at cardinal angle and may represent a weak eye-spot while at the posterior end, which is also slightly enlarged, a vertical rib joins the postero-ventral angle across the lateral surface. A similar but much weaker lateral rib is present on the anterior lateral surface. Inner lamella is of median width anteriorly with a narrow vestibule, details not observed posteriorly. Pore canals and muscle scars not observed. Hinge, only observed in RV, appears hemimerodont with slightly sinuous median grove. Teeth, weakly crenulate although this appearance may be due to preservation. Sexual dimorphism is apparent, the (?)male RV's having a straight dorsal margin whereas in the larger (?)females this feature is convex.

Dimensions:

$$
\begin{array}{rll}
\text { M RV } & \mathrm{l}=0.44 \mathrm{~mm}, \mathrm{~h}=0.22-0.23 \mathrm{~mm} ; \\
\text { LV } & \mathrm{l}=0.44-0.46 \mathrm{~mm}, \mathrm{~h}=0.22 \mathrm{~mm} . \\
\text { F RV } & \mathrm{l}=0.45-0.46 \mathrm{~mm}, \mathrm{~h}=0.24-0.26 \mathrm{~mm} ; \\
\text { LV } & \mathrm{l}=0.40 \mathrm{~mm}, \mathrm{~h}=0.23 \mathrm{~mm} .
\end{array}
$$

Remarks: Analysis of material from D.S.D.P. site 547 reveals that this species is also present in sample 547-11, CC. Although none of the specimens figured by Bate et al. (1984) appear to represent species, Genus Indeterminate $D$ is similar.

Specimens from the Upper Toarcian of Mochras differ in that they lack the vertically aligned ribs, have more pronounced antero- and postero-dorsal nodes and possess a coarse surface punctation, these younger specimens are also notably larger $(1=0.50 \mathrm{~mm}, \mathrm{~h}=0.24 \mathrm{~mm})$ and are therefore probably not conspecific.

Distribution: But for one record in the mid-margaritatus zone the species ranges from the mid-spinatum to the top of the tenuicostatum zone at Mochras. Also present in the Upper Pliensbachian? of D.S.D.P. site 547.

Genus Ektyphocythere Bate, 1963

Type species: Ektyphocythere triangula (Brand, 1961) Ektyphocythere bizoni Ainsworth, 1986

(Pl.2 figs 1, 2).

1986 Ektyphocythere bizoni Ainsworth: 315, P1.8, figs 1-4. Material: Mochras $>150$ Car, $>200$ V.

Remarks: Originally described from the Toarcian/Aalenian of the Fastnet Basin (Ainsworth, 1986). The type material consisted of only twelve carapaces with internal details described from the present authors', Mochras, material. Similarly ornamented species have been recorded from Toarcian sediments throughout Europe, e.g. E. furcata (Stoermer \& Weinholz, 1967); $E$. vitilis (Apostolescu, Magne \& Malmoustier, 1961). The species described by Stoermer \& Weinholz, originally as a sub-species of $E$. vitilis, is very similar to the present material, however, the former is generally larger with more robust ribbing (comparative material made available from Achdorf by $\mathrm{Dr} \mathrm{H}$. Knitter). There is some overlap in the size ranges and the two are undoubtedly closely related and could be considered as sub-species given their geographical separation and the difference in size.

(all sizes in $\mathrm{mm}$.)

\begin{tabular}{llll} 
Ektyphocythere bizoni & \multicolumn{2}{l}{ Ektyphocythere furcata } \\
Ainsworth & This & Weinholz & This \\
1986 & work & 1967 & work \\
$0.55-0.65$ & $0.55-0.63$ & $0.57-0.66$ & $0.60-0.66$ \\
$0.31-0.35$ & $0.28-0.38$ & $0.30-0.39$ & $0.32-0.40$
\end{tabular}

$\begin{array}{llllll}\text { Length (mm) } & 0.55-0.65 & 0.55-0.63 & 0.57-0.66 & 0.60-0.66 \\ \text { Height (mm) } & 0.31-0.35 & 0.28-0.38 & 0.30-0.39 & 0.32-0.40\end{array}$

In the size ranges given above, the values for both the $L V$ and $\mathrm{RV}$ have been combined. The differences in the ranges clearly 


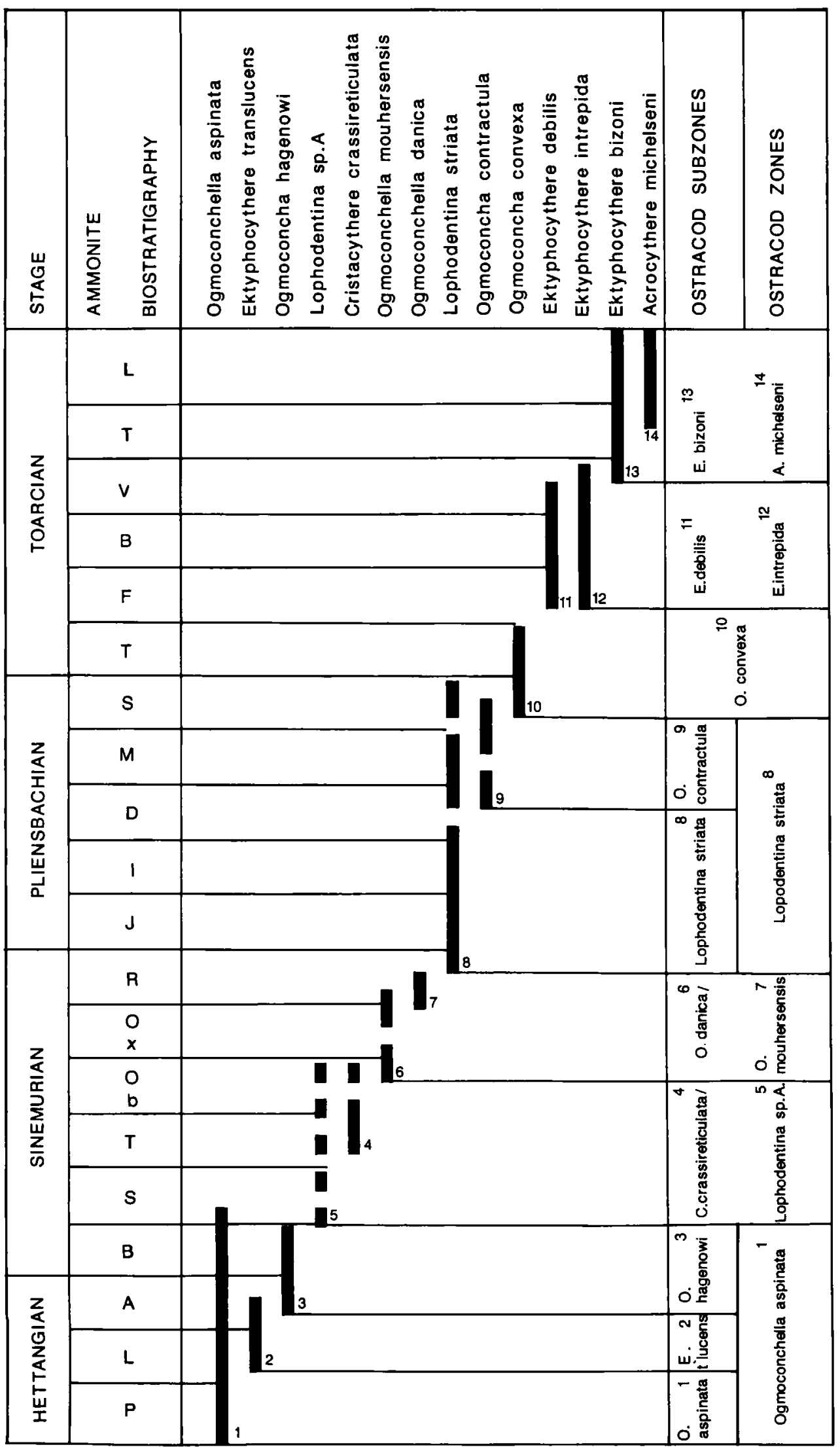


show the Fastnet specimens, attributed to E. bizoni, to have a shorter and lower outline. The specimens recorded by Lord (1974) as E. vitilis have a length range of $0.52-0.58 \mathrm{~mm}$ and a height range of $0.27-0.34 \mathrm{~mm}$. These are obviously much closer to E. bizoni, indeed, some of these dimensions are even smaller. Distribution: In the Fastnet Basin, poor stratigraphical control prevents an accurate assessment of the range of the species in the type area, however, in the Mochras section E. bizoni first appears near the top of the variabilis zone, becoming an abundant faunal element towards the top of the borehole. Since there is an almost complete Lower Jurassic section at Mochras it is assumed that the species ranges into the Middle Jurassic.

\section{OSTRACOD BIOZONATION.}

Seven zones and five sub-zones are proposed, based where possible, on the presence of species known to be abundant or at least usually present if only in small numbers. All zones and sub-zones are assemblage zones named after the most abundant and/or numerically dominant species within the interval. The base of each zone/sub-zone is taken at the first appearance of a zonal/sub-zonal marker. The proposed scheme is outlined in Fig. 1 with reference to the ammonite stratigraphy (after IvimeyCooke in Woodland (ed.) 1971). The Ostracod Zones and Subzones are described below beginning with the oldest.

The stratigraphical ranges of many of the species referred to below often differ from their ranges recorded elsewhere, thus a direct correlation between the present scheme and other sections is not practical at present. Accessory species are included where they are numerically important within the asemblages, with less importance being attached to their total temporal distribution.

\section{Ogmoconchella aspinata Ostracod zone.}

Author: Michelsen (1975).

Definition: Base of the section to the first appearance of Lophodentina sp.A.

Range: Base of the Mochras section (within the planorbis zone) to topmost bucklandi zone, Lower Sinemurian.

Remarks: The zone is equivalent to almost the total range of the marker species Ogmoconchella aspinata (Drexler) being common in most samples, however, the youngest sample in which it was recorded has been assigned to the overlying zone. The zone is subdivided into three, the youngest two sub-zones identified on the presence of other marker species and the third sub-zone characterised by the abundant, often monospecific assemblage of aspinata itself. The zonal marker is a common constituent of lowermost Jurassic marine sediments in NorthWest Europe.

\section{Ogmoconchella aspinata Ostracod sub-zone:}

Author: Defined here.

Definition: Base of the section to the first appearance of Ektyphocythere translucens (Blake).

Range: Represented by the two lowest samples at Mochras (planorbis and lower liasicus zone).

Remarks: Low diversity assemblages, monospecific faunas being common, aspinata generally representing over $95 \%$ of the fauna.

Accessory species: Paracypris sp. and poorly preserved representatives of the genus Lophodentina.

\section{Ektyphocythere translucens Ostracod sub-zone:}

Author: Defined here.

Definition: From the first appearance of Ektyphocythere translucens (Blake, 1876) to the first appearance of $O$. hagenowi Drexler, 1958.

Range: Mid-liasicus to mid-angulata zones of the Hettangian. Remarks: The uppermost range of $E$. translucens overlaps with the lower range of hagenowi.

Accessory species: Cytherelloidea circumscripta (Blake, 1876) and Ektyphocythere moorei (Jones, 1872).

\section{Ogmoconcha hagenowi Ostracod sub-zone:}

Author: Defined here.

Definition: From the first appearance of $O g m o c o n c h a$ hagenowi Drexler to the first appearance of Lophodentina sp. A.

Range: Mid-angulata zone through to the lower part of the semicostratum zone, Upper Hettangian to Lower Sinemurian. Remarks: In the uppermost part of the sub-zone, hagenowi Drexler is less common and is indeed absent from two samples. Accessory species: Cytherella concentrica Field, 1966; Paradoxostoma? pusillum Michelsen, 1970 and Nanacythere spp.

Cristacythere crassireticulata/Lophodentina sp. A. Ostracod zone.

Author: Defined here

Definition: First appearance of Lophodentina sp. A. to the first appearance. of danica Michelsen.

Range: Basal semicostatum to mid-obtusum zone, Lower Sinemurian to the lowest part of the Upper Sinemurian.

Remarks: The zone is difficult to delimit accurately since ostracod diversity and abundance is very low throughout the interval. The two zonal markers are the most common species in this interval crassireticulata Michelsen (Pl.3 fig.3) was also established as a zonal marker by Michelsen (1975) where, together with Cristacythere betzi (Klingler \& Neuweiler), it defined the upper part of the Lower Sinemurian. This is in broad agreement with the present analysis although betzi has not been positively identified in the present section.

Accessory species: Representatives of the genus Ektyphocythere poorly preserved but ornamented by a longitudinally aligned reticulate network. Supplementary species common at various levels within the zone include Cristacythere osmanvillae (Donze); see Pl.3 fig.4, Ektyphocythere intermedia (Gramann) and representatives of the genus Isobythocypris. 
Ogmoconchella danica/Ogmoconchella mouhersensis Ostracod Zone.

Author: Defined here.

Definition: Base of the zone marked by the first appearance of Ogmoconchella danica Michelsen, top of the zone marked by first appearance of $L$. striata sp. nov.

Range: A short zone ranging from mid-obtusum to midraricostatum zone and equivalent to much of the Upper Sinemurian.

Remarks: danica, although rarely abundant, is the most consistently occurring species in the zone and is therefore regarded as a zonal marker. Ogmoconchella mouhersensis is recorded in the upper part of the zone, often representing a significant part of the assemblage, particularly where danica is absent. Although both species are recorded as having extensive stratigraphical ranges in other parts of Europe, they occur within a relatively short time interval in Mochras where they often dominate the assemblages. As with the previous two zones, the present zone bears similarities with the scheme proposed by Michelsen (1975). The latter work included an danica zone which ranged from Upper Sinemurian to Lower Pliensbachian and consisted of three sub-zones. The present zone is thought to correlate with the two lowest sub-zones of Michelsen's scheme.

Accessory species: Isobythocypris spp., Ogmoconchella bispinosa (Grundel) together with other, indeterminate Metacopina.

Lophodentina striata Ostracod zone.

Author: Defined here.

Definition: First appearance of $L$. striata sp. nov. to first appearance of convexa sp. nov.

Range: Upper raricostatum to the mid-spinatum zone, uppermost Sinemurian to the uppermost Pliensbachian and is divided into two sub-zones.

Remarks: Chracterised by the presence of Lophodentina striata sp. nov. a species which, although never abundant, is present in most samples within the zone. The present zone covers the stratigraphical interval which Michelsen assigned to both the upper sub-zone of his danica zone, i.e. the G. apostolescui K.(K.) foveolata sub-zone, and to the adenticulata - N. simplex zone. Of these zonal markers only adenticulata is present in any great numbers within the Mochras section. It also appears that few of the accessory species recorded from the Danish zonation are present at Mochras, suggesting that palaeogeographical links between Mochra and Northern Europe were less well established at this time than they had been previously. The zone is further divided into two sub-zones.

Accessory species: Liasina lanceolata (Apostolescu), Cytheropteron aff cavatum Michelsen (Pl.3 fig.1) and Pleurocythere sp. B. (Pl.3 fig.7) The latter two together with the zone fossil have their first appearance at the base of the zone. Although all three species are known to range above the present zone they are most abundant within it.

\section{Lophodentina striata Ostracod sub-zone}

Author: Defined here.

Definition: First appearance of contractula Triebel, to the first appearance of convexa sp. nov.

Range: Upper davoei to lower spinatum zone, uppermost Lower Pliensbachian to Upper Pliensbachian.

Remarks: The sub-zonal marker is by no means a consistent faunal element but where it does occur it is often the most abundant species. Poor preservation in many samples within the striata zone precludes the recognition of an accurate zonation system, particularly for the lower part of the Upper Pliensbachian, which in the Mochras Borehole is a period of low diversity and low faunal turnover with the Metacopina a dominant faunal element.

Accessory species: Cytheropteron? sp. A. (Pl.3 fig.2). and Eucytherura cf. E. liassica Bate \& Coleman.

\section{Ogmoconcha convexa Ostracod zone.}

Author: Defined here.

Definition: The lower limit is marked by the first appearance of both the zonal marker Ogmoconcha convexa sp. nov. and Oligocythereis? sp. The upper limit of the zone is marked by the last occurrence of Liasina vestibulifera Gramann and the extinction of all metacopine ostracods.

Range: Mid-spinatum to lowermost falciferum, a short zone across the Pliensbachian/Toarcian boundary.

Accessory species: Oligocythereis? mochrasensis sp. nov., Ektyphocythere knitteri Reigraf and Kinkelinella tenuicostati Martin. Liasina lanceolata (Apostolescu) is also abundant in the zone while the uppermost sample is characterised by abundant Bairdia donzei Herrig.

\section{Ektyphocythere debilis/Ektyphocythere intrepida Ostracod} zone.

Author: Defined here.

Definition: The base is marked by the first appearance of Ektyphocythere debilis and Ektyphocythere intrepida both originally described by Bate \& Coleman (1975) while the top of the zone is marked by the first appearance of E. bizoni Ainsworth.

Range: Lowermost falciferum to the uppermost variabilis zone, Lower and Middle Toarcian.

Remarks: Although the zone has not been formally subdivided, the following observations can be made. The lowermost samples in the zone, following the extinction of the Metacopina, are distinctive in that the assemblages are almost exclusively composed of cypridacean ostracods which are poorly preserved and as such do not typify the zone as a whole. Of these, only Liasina lanceolata (Apostolescu) has been positively identified.

The marked faunal change at the top of the underlying zone 


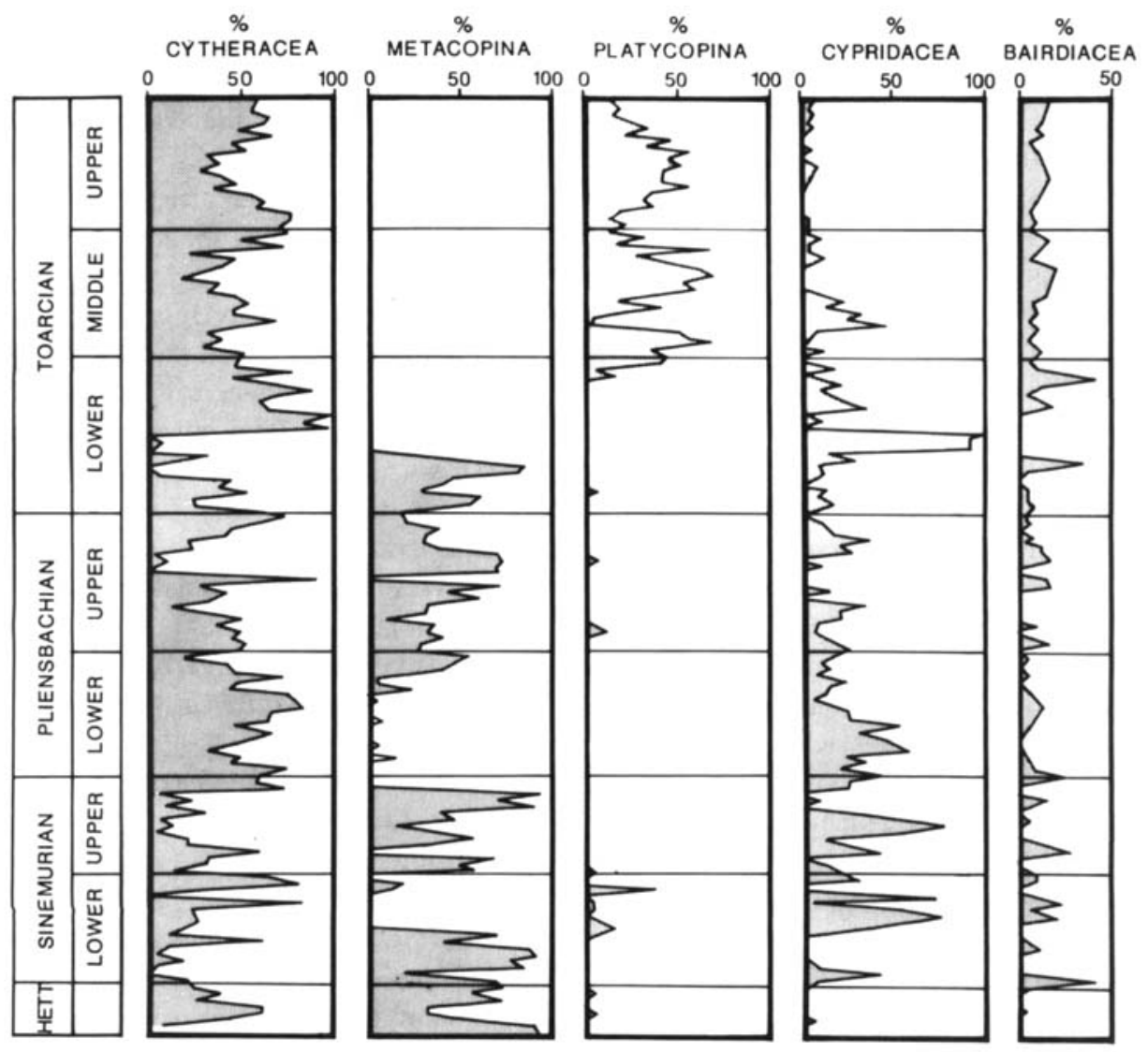

Fig 2 Faunal composition of the Mochras Borehole.

is obviously an easily recognised break and therefore the poorly preserved, Cypridacea-dominated levels are best interpreted as belonging to the present zone. Many of the species appearing within the Toarcian continue to the top of the section and for that reason first appearance data are more commonly employed for subdivision than total ranges. The present zone includes much of the stratigraphical interval studied by Bate $\&$ Coleman (1975) from the East Midlands. Their proposed zonation scheme established three zones on the presence of five marker species. Two of those species, Kinkelinella persica Bate \& Coleman and Camptocythere toarciana Bate \& Coleman, are not recorded in Mochras.

Bate \& Coleman's (op. cit.) lowest zone was based on the presence of Kinkelinella sermoisensis (Apostolescu) and $E$. intrepida Bate \& Coleman while the uppermost zone was based on the presence of $E$. debilis Bate \& Coleman. Since the latter two species have roughly concurrent ranges in Mochras but are stratigraphically separated in the East Midlands, it would appear that there is a marked difference between the two areas possibly due to a barrier of some description (Welsh landmass?) The former species ranges throughout most of the Middle and Upper Toarcian at Mochras and is therefore of little biostratigraphical value.

Accessory species: Upper falciferum zone samples are characterised by common records of Kinkelinella sermoisensis
(Apostolescu) and Praeschuleridea pseudokinkelinella Bate \& Coleman. The uppermost falciferum zone is marked by the first appearance in the section of Cytheropteron alafastigatum Fischer and Rutlandella transversiplicata Bate \& Coleman. The lowest variabilis zone is marked by the first appearance of Cytherelloidea cf. C. catenulata (Jones \& Sherborn), followed by the subsequent appearance of Bairdiacypris triangularis Ainsworth and Praeschuleridea species.

\section{Ektyphocythere bizoni/Acrocythere michelseni Ostracod} zone.

Author: Defined here.

Definition: From the first appearance of Ektyphocythere bizoni Ainsworth to the top of the section.

Range: Uppermost variabilis to the top of the levesquei zone, aalensis sub-zone, Upper Toarcian.

Remarks: $E$. bizoni Ainsworth is present and often abundant throughout the section while $A$. michelseni Finger is present in most samples. Throughout this zone the overall trend of increasing faunal diversity, which began following the extinction of the Metacopina, continues to the top of the section. Preservation is much better in the more diverse Middle and Upper Toarcian faunas than in the Lower Toarcian and it would be possible to produce an extremely fine zonation scheme for the younger interval based on these assemblages. This, however, 


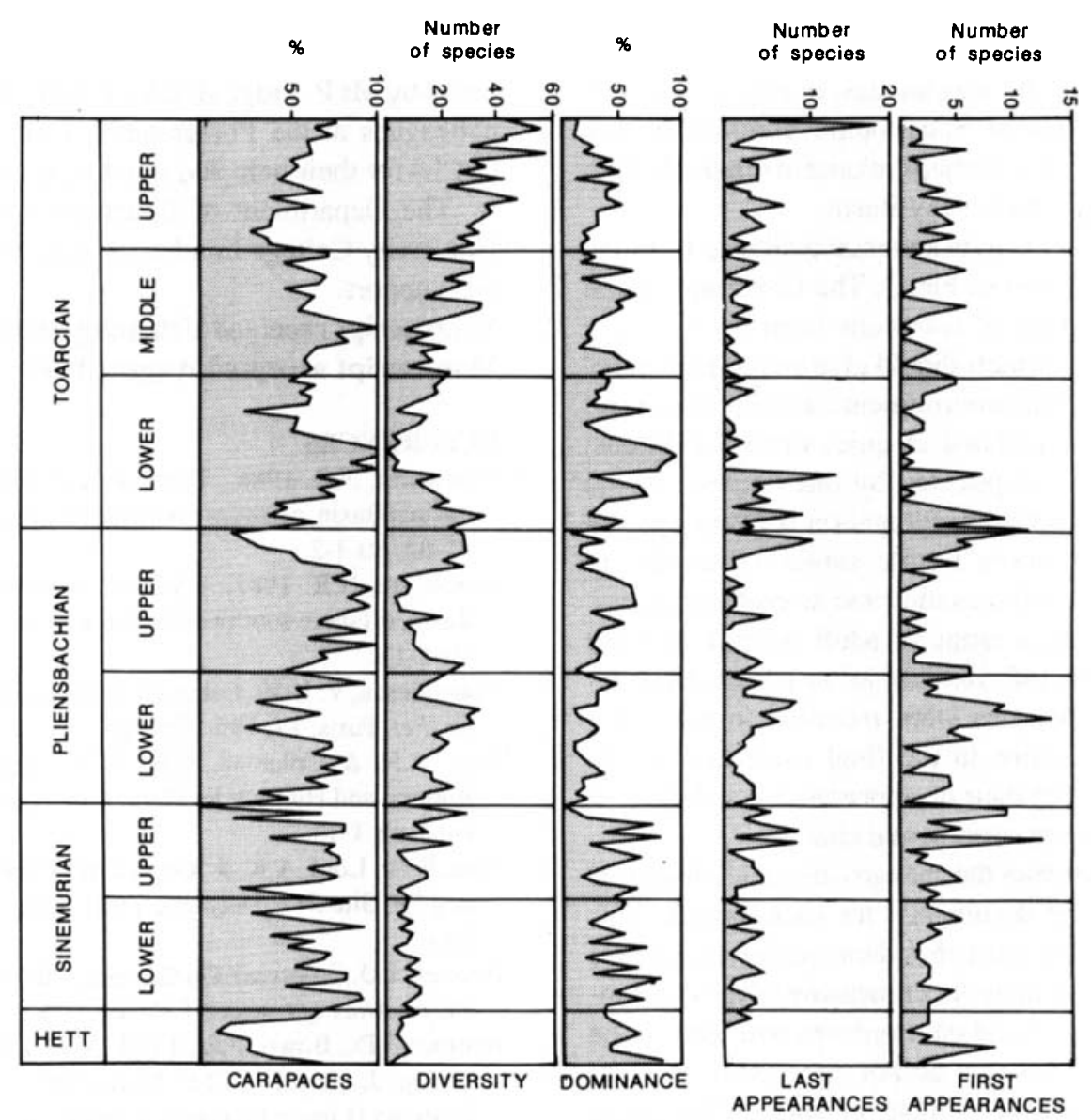

Fig 3 Faunal turnover and environmental evidence within the Mochras Borehole.

may only be of local application.

A direct comparison with the Upper Toarcian ostracod zonation of Southern Germany proposed by Knitter (1984) reveals that eleven of his twenty-two zonal markers are not present in Mochras, while five are present in only limited numbers, and the remaining species common to both areas appear to have different ranges in Mochras.

Accessory species: Cardobairdia spp. (Pl.3 fig.5), Pleurocythere sp. C. (Pl.3 figs 6, 8, 9, 10), Rutlandella transversiplicata, Bate \& Coleman and Cytherella toarcensis Bizon.

\section{FAUNAL COMPOSITION \& ENVIRONMENTAL EVI- DENCE IN THE MOCHRAS BOREHOLE.}

The data presented in Figs $2 \& 3$ show the changing faunal composition of the ostracoda at sub-order/superfamily level and also the environmental evidence at Mochras, both of which are presented numerically. It is acknowledged that such data has its limitations, therefore only generalised conclusions are presented. It should be noted that the sampling strategy was strongly influenced by sediment type (e.g. the Toarcian shales being easier to process). Furthermore none of the data sets take into account sample size. With these comments in mind it can be concluded that changes in the ostracod faunas recovered reflect environmental changes in the sequence.
The faunal composition of the Mochras Borehole is presented in Fig. 2. The y-axes represent the percentage which each group constitutes of the total number of specimens in each sample. The plots show the alternating numerical dominance of the Cytheracea, Metacopina, and to a lesser extent the Cypridacea and Bairdiacea, within the Hettangian to lower Toarcian part of the sequence.

In particular it should be noted that the Metacopina were by no means important or uniformly common throughout this interval. Their disappearance at the uppermost tenuicostatum zone (not at the Pliensbachian-Toarcian boundary) is followed by a, short lived, cypridacean dominated fauna which is replaced by an apparently cyclic relationship between the Cytheracea and the Platycopina throughout the Middle and Upper Toarcian. The latter group represents a negligible constituent of the fauna prior to this point in the section and this may reflect the filling of the metacopine niche by the Platycopina. It is possible that such alternations in the dominance of one group over another results in changes in water depth which will in turn affect primary parameters determining the distribution of ostracods.

It has been suggested by Whatley (pers. comm.) that the Platycopina are more tolerant of low-oxygen conditions than other benthic ostracod groups since they may possess the ability to increase the flow of water through the carapace due to 
circulatory movements of the appendages. It may be inferred, therefore, that the periods of platycopine dominance may represent low-oxygen events, perhaps related to relatively high sea-level stands in the Cardigan Bay Basin.

The faunal turnover and environmental evidence from the Mochras section is displayed in Fig. 3. The first graph in the series shows the percentage of ostracods from each sample represented by carapaces, which should give an indirect measurement of the energy of the environment since carapaces are less likely to become dissociated in quiet-water conditions. Such interpretations are complicated by the variation in the degree of post-mortem valve disaggregation between species and the possible loss of more fragile single valves during processing. This data set combines adult and juvenile carapaces. In two samples, however, a range of adult through to early juvenile (A-5) carapaces (of convexa sp. nov.) has been recorded. These thanatocoenoses were recorded in the upper tenuicostatum zone just prior to the final extinction of the Metacopina suggesting that their disappearance was linked, if not entirely due, to some environmental change.

The second graph indicates the changes in species diversity. The third graph plots the dominance for each sample; this shows what percentage the most abundant species constitutes in each sample thus giving an indirect measure of the environmental stability since a stressed environment will tend to be dominated by one, opportunistic and/or successful, species. The final two graphs plot the number of species becoming extinct and those having first appearance in each sample.

\section{SUMMARY}

The extensive Lower Jurassic sequence at Mochras has yielded a distinctive and diverse ostracod fauna which suggests the presence of physical and/or chemical oceanographical barriers between western Wales and the rest of mainland Britain at that time. Significantly, a strong faunal correlation exists with the Fastnet Basin material described by Ainsworth $(1986,1987)$ and it is hoped that these similarities can be investigated in more detail in the future. There also exists a correlation between the Mochras material and the ostracod fauna described by Bate $e t$ al. (1984) from D.S.D.P. site 547, again suggesting stronger faunal connections to the south and west of Britain rather than to the east.

\section{ACKNOWLEDGMENTS.}

The author is greatly indebted to Dr A.R. Lord for critically reading the manuscript and for his guidance during the course of this research. Mr J. Davy of University College London is thanked for his tireless technical assistance. Material from the Mochras section was kindly made available by Professors J.R. Haynes and R.C. Whatley, University College of Wales, Aberystwyth. Dr P. Copestake (I.E.D.S Ltd.), Dr B. Johnson (Haliburton Geo Consultants) and Mr P.F. Sherrington (Petrocanada) kindly provided various residues and picked material from Mochras. Dr N.R. Ainsworth is acknowledged for his useful discussion and comments. Diagrams were pre- pared by Mr P. Judge (UEA). Finally, I wish to thank all of my colleagues at the Postgraduate Unit of Micropalaeontology (UCL) for their help and good humour.

The Department of Education for Northern Ireland and University College London are acknowledged for their financial support.

Manuscript received February 1990

Manuscript accepted August 1990

\section{REFERENCES}

Ainsworth, N.R. 1986. Toarcian and Aalenian Ostracoda from the Fastnet Basin, offshore South-West Ireland. Geol. Surv. Ire. Bull. 4, 41-62, pls 1-2.

Ainsworth, N.R. 1987. Pliensbachian Ostracoda from the Fastnet Basin, offshore southwest Ireland. Geol. Surv. Ire. Bull. 3, 277-336, pls 1-11.

Apostolescu, V. 1959. Ostracodes du Lias du Bassin de Paris. Rev. Inst. Fr. Pet, Paris. 14, 795-826, pls 1-3.

Bate, R.H. \& Coleman, B.E. 1975. Upper Lias Ostracoda from Rutland and Huntingdonshire. Bull. Geol.Surv. G.B. London. 55, 1-42, pls 1-15.

Bate, R.H., Lord, A.R. \& Riegraf, W, 1984. Jurassic Ostracoda from Leg 79, Site 547. Deep Sea Drill. Proj. Initial. Rep. 79, 703-710, 5 pls.

Boomer, I.D. (in-press). On Gammacythere klingleri Boomer sp. nov. Stereo-Atlas of Ostracod Shells..

Boomer, I.D., Bown, P.R., Lord, A.R., Lowry, F.M.D., Page, K. \& Riding, J. (in-press). The Stratigraphy of the late Pliensbachian/ Toarcian (Lower Jurassic) sequence at Ilminster, Somerset. Geol. Mag.

Donze, P. 1967. Les Ostracodes du sondage Laneuveville-devantNancy (Lotharingien de la region type). Sci. Terre, Nancy, 12, 71 92.

Donze, P. 1968. Especes nouvelles d'Ostracodes du Lias inferieur Normand. Bull. Soc'. Linn. Normandie 9, Series 10, 78-87, 2 pls.

Drexler, E. 1958. Foraminiferen und Ostracoden aus dem Lias von Siebledingen/Pfalz. Geol. Jb. 75, 475-554, 8pls.

Klingler, W. 1962. Lias Deutschlands. 73-122, 6pls. In D. Simon, W. \& Bartenstein, H. (Eds). Leitfossilien der Mikropalaontologie 432 Berlin.

Klingler, W. \& Neuweiler, F. 1959. Leitende Ostracoden aus dem Deutschen Lias beta. Geol. $\mathrm{Ib}$. 76, 373-410, 6pls.

Knitter, H. 1984. Ostracod Biostratigraphy of the Upper Toarcian in Southern Germany. In Michelsen, O. \& Zeiss, A. (Eds). International Symposium on Jurassic Stratigraphy. Vol. 1, 252-258.

Knitter, H. \& Riegraf, W. 1984. Biostratigraphie (Cephalopoden, Ostracoden) des Oberen Toarcian von Blumberg-Achdorf/Wutach und Weilheim/Teck (Baden-Wurttemburg). Jahrb. Geol. Landes. Baden-Wurtt. 26, 57-97, 5pls.

Michelsen, O. 1975. Lower Jurassic biostratigraphy and Ostracods of the Danish Embayment. Danmarks Geol. Undersogelse copenahgen. 104, 1-289, pls 1-42.

Stoermer, N. \& Weinholz, E. 1967. Mikrobiostratigraphie an der Lias/ Dogger-Grenze in Bohrungen nordlich der Mitteldeutschen Haptscholle. Jb. Geol. 1, (1965) 533-591, pls 1-10.

Woodland, A.W.(Ed.). 1971. The Llanbedr (Mochras Farm) Borehole. Inst. Geol. Sci. Rep. 71/18, 1-115. 